\title{
Metal Pollution in Coastal Sediments
}

\author{
Yu Qian ${ }^{1,3}$ - Weiguo Zhang ${ }^{2} \cdot$ Lizhong $\mathrm{Yu}^{2} \cdot$ Huan Feng ${ }^{1}$
}

Published online: 24 October 2015

(C) Springer International Publishing AG 2015

\begin{abstract}
Coastal sediment is a vital habitat for aquatic and marine life in coastal ecosystem. However, urbanization and economic development in coastal areas have resulted in environmental problems globally. Due to coastal development such as new industrial facilities and commercial port expansion, anthropogenic metals are introduced to the adjacent areas. Therefore, metal pollution in coastal areas is one of the focused environmental concerns. Sediment quality in coastal zone reflects the long-term environmental status because it keeps a record of the development in the area. In this review paper, sediment metal concentrations in 52 selected sites worldwide are summarized for evaluation of the coastal environmental quality. The results from this study can be applied to science-based policy formulation and ecological restoration/rehabilitation practices in an integrated coastal zone environmental management.
\end{abstract}

Keywords Coastal sediment $\cdot$ Metal $\cdot$ Enrichment factor $\cdot$ Hazardous quotient $\cdot$ Risk assessment

This article is part of the Topical Collection on Sediment and Other Pollutions

Huan Feng

fengh@montclair.edu

1 Department of Earth and Environmental Studies, Montclair State University, Montclair, NJ 07043, USA

2 State Key Laboratory of Estuarine and Coastal Research, East China Normal University, Shanghai 200062, People's Republic of China

3 Present address: School of Ecology and Environmental Sciences, Yunnan University, Kunming, Yunnan 650091, People's Republic of China

\section{Overview}

Metals with different speciations and oxidation states are naturally present in the earth crust [1]. Depending on the rock type, geophysical condition, and geographical location around the world, metal concentrations in sediments, soils, and water present as naturally weathered products from the earth crust can be different from place to place $[2,3]$. Trace amount of metals is essential micronutrients for the growth and metabolism of many organisms [4]. However, metals in excessive amount can be toxic to organism and cause ecological toxicity [4]. Anthropogenic metal input associated with the urbanization and industrialization in the twentieth century has increased dramatically in the coastal areas and is drawing increasing attention around the world because about $80 \%$ of the pollutants from human activities are introduced into coastal environment [1,5]. Therefore, metal pollution in the coastal sediments has become a major environmental problem because it threatens the economic and ecological value of the coastal area.

Coastal environment is a complex system involving physical, chemical, and biological processes that play important roles in metal biogeochemical cycle. However, anthropogenic input has caused metal pollution in the coastal area. The sources include mining, metal product fabrication, solid waste disposal, fossil fuel combustion, and municipal/industrial waste effluent $[1,6]$. Industries, such as foundry, paper processing, laundry, tannery, and dye works, can emit toxic metals and discharge wastewater to the adjacent estuaries and coastal areas [7, 8]. Acid rain can leach metals and increase the mobility of toxic metals from pollutant sources to the environment [9]. Once enter coastal environment, the toxic metals will mainly accumulate in the sediments because of particle 
scavenging and settling. Therefore, high concentrations of toxic metals are often found in sediments in many industrialized urban coastal areas as a consequence of industrialization and urban development with population growth in the areas [10-14]. It is well known that finegrained sediments are the main carriers of the toxic metals because of its higher specific surface area. Many studies have shown that coastal sediments are repository for metal pollutants and provide time-integrated records of pollution history [11, 15-19]. This paper summarizes the metal concentrations in coastal sediments in selected areas and reflects the environmental pollution and the potential ecological risk associated with urbanization and economic development.

\section{Metal Concentrations in Coastal Sediments}

In this review, sediment metal concentrations in 52 selected coastal sites around the world were summarized based on the published literatures (Table 1 and Fig. 1). These publications are based on original field studies in six continents (Africa, Asia, Australia, Europe, North America, and South America) including 20 countries, e.g., France [36], Spain [42, 43], Greece [37, 38], Turkey [24], Albania [35], Italy [39, 41], USA [7, 47-49], French Guiana [53], Mexico [46], China [12, 26-28], India [30, 31], Korea [29], Azerbaijan [23], Iran [23], Kazakhstan [23], Russia [23], Fiji [34], Australia [33], and Africa [20]. Table 1 summarizes sediment metal concentrations in selected areas around the world. Average metal concentrations at each site range from 0.096 to $10.9 \%$ for $\mathrm{Al}, 0.21-13.8 \%$ for $\mathrm{Fe}, 3-81 \mathrm{~kg}^{-1}$ for $\mathrm{Ag}$, $0.04-998 \mathrm{mg} \mathrm{kg}^{-1}$ for $\mathrm{Cd}, 1.0-463 \mathrm{mg} \mathrm{kg}^{-1}$ for $\mathrm{Cr}$, $0.5-$ $604 \mathrm{mg} \mathrm{kg}^{-1}$ for $\mathrm{Cu}, 0.01-1.8 \mathrm{mg} \mathrm{kg}^{-1}$ for $\mathrm{Hg}, 0.4-4$, $643 \mathrm{mg} \mathrm{kg}^{-1}$ for $\mathrm{Mn}, 2-240 \mathrm{mg} \mathrm{kg}^{-1}$ for $\mathrm{Ni}, 3-2$, $369 \mathrm{mg} \mathrm{kg}^{-1}$ for $\mathrm{Pb}$, and $7-4,430 \mathrm{mg} \mathrm{kg}^{-1}$ for $\mathrm{Zn}$, respectively (Table 1). The wide variations in toxic metal concentrations reflect the different natural mineral compositions in the sediments as well as anthropogenic input in some of these coastal areas.

\section{Sediment Pollution Assessment}

Excess amount of toxic metals in environment can cause pollution problems in coastal areas. To evaluate metal pollution in the sediments, metal enrichment factor (EF) has been widely used as the assessment criteria to screen sediment metal concentrations of environmental concern (e.g., $[7,11,12,28,55-60])$. Because EF values can be used to distinguish natural metal concentrations from those of anthropogenic origin, it is widely used for sediment quality assessment (e.g., $[7,11,12,55,57,58,60$, 61]). Mathematically, it is expressed as (e.g., [62]):

$\mathrm{EF}=\frac{\left(\frac{\mathrm{Me}}{\mathrm{Al} \text { or Fe }}\right)_{\text {Sample }}}{\left(\frac{\mathrm{Me}}{\mathrm{Al} \mathrm{or} \mathrm{Fe}}\right)_{\text {Background }}}$

where $\mathrm{Me}$ is the metal concentration of concern, $\left(\frac{\mathrm{Me}}{\mathrm{Al} \text { or } \mathrm{Fe}}\right)$ Sample is the metal to $\mathrm{Al}$ or $\mathrm{Fe}$ ratio in the sample, and $\left(\frac{\mathrm{Me}}{\mathrm{Al} \mathrm{or} \mathrm{Fe}}\right)$ Background is the metal to $\mathrm{Al}$ or $\mathrm{Fe}$ ratio in the background. $\mathrm{Al}$ and $\mathrm{Fe}$ are used here as geochemical normalization elements because both $\mathrm{Al}$ and $\mathrm{Fe}$ are the most abundant elements in the earth crust $[2,3]$. The metal background concentration should be derived from the sampling site if available [63]. However, the background data are not readily available in most of the cases. For metal EF calculation, when the local metal background values are not available, the upper continental crust values can be used as the background values [64-71]. In this case, metal concentrations in the upper continental crust [3] were adopted as alternatives for the background values.

Metal EF values indicate the extent of metal enrichment in the sediments and can be used as sediment assessment reference criteria $[60,72,73]$. As a simple guideline, $\mathrm{EF} \approx 1$ indicates natural crustal origin, whereas $\mathrm{EF}>10$ suggests anthropogenic source [74]. Zhang and Liu [60] also recommend that $0.5<\mathrm{EF}<1.5$ suggests that the metals may be entirely from crust natural weathering processes, whereas $\mathrm{EF}>1.5$ indicates that a significant portion of the metal is delivered from non-crustal materials. In another classification, metal EF values are divided into five categories based on the degree of enrichment, i.e., (1) $\mathrm{EF}<2$ suggests deficiency to minimal enrichment, (2) $\mathrm{EF}=2-5$, moderate enrichment, (3) $\mathrm{EF}=5$ 20, significant enrichment, (4) $\mathrm{EF}=20-40$, very high enrichment, and (5) EF $>40$, extremely high enrichment [72].

The estimation of metal EF relies on the data availability of the geochemical normalization element in the site of interest. We managed to estimate the metal EF values for 38 selected coastal areas around the world. The results show that metal EF values vary widely from minimal to extremely high enrichment (Fig. 2). Specifically, the EFs calculated from the average metal concentrations at each site range from 7.2 to 43 for As $(n=$ 9), $0.5-1,582$ for $\mathrm{Cd}(n=26), 0.1-15$ for $\mathrm{Cr}(n=31)$, $0.07-29$ for $\mathrm{Cu}(n=34), 0.02-5$ for $\mathrm{Mn}(n=26), 0.3-$ 56 for $\mathrm{Ni}(n=33), 0.6-130$ for $\mathrm{Pb}(n=31)$, and $0.8-44$ for $\mathrm{Zn}(n=38)$, respectively (Fig. 2).

As shown in Table 2, cases of moderate to high metal enrichment (EF>2) account for $19-100 \%$, depending on the metals, of which relatively high 


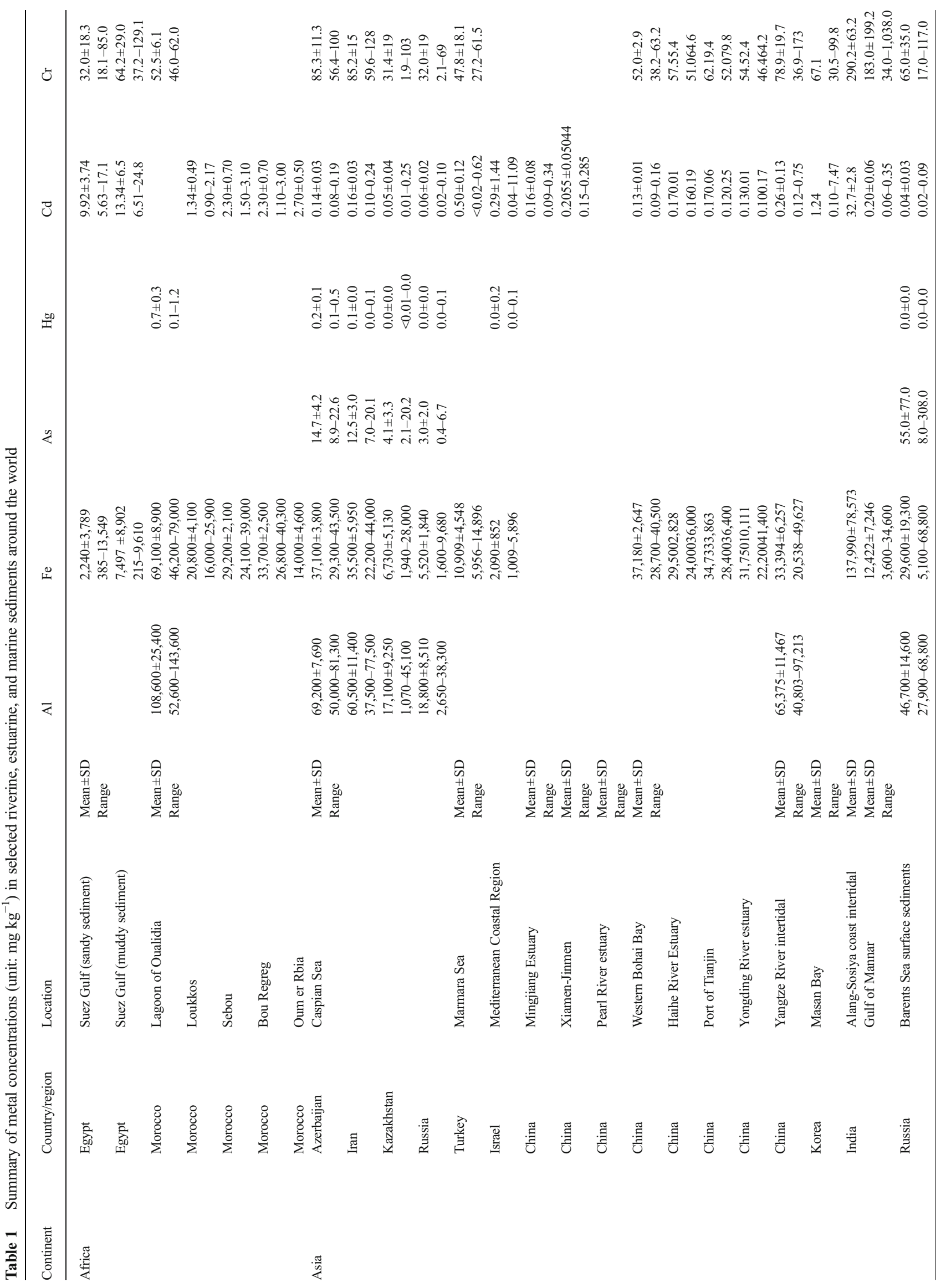




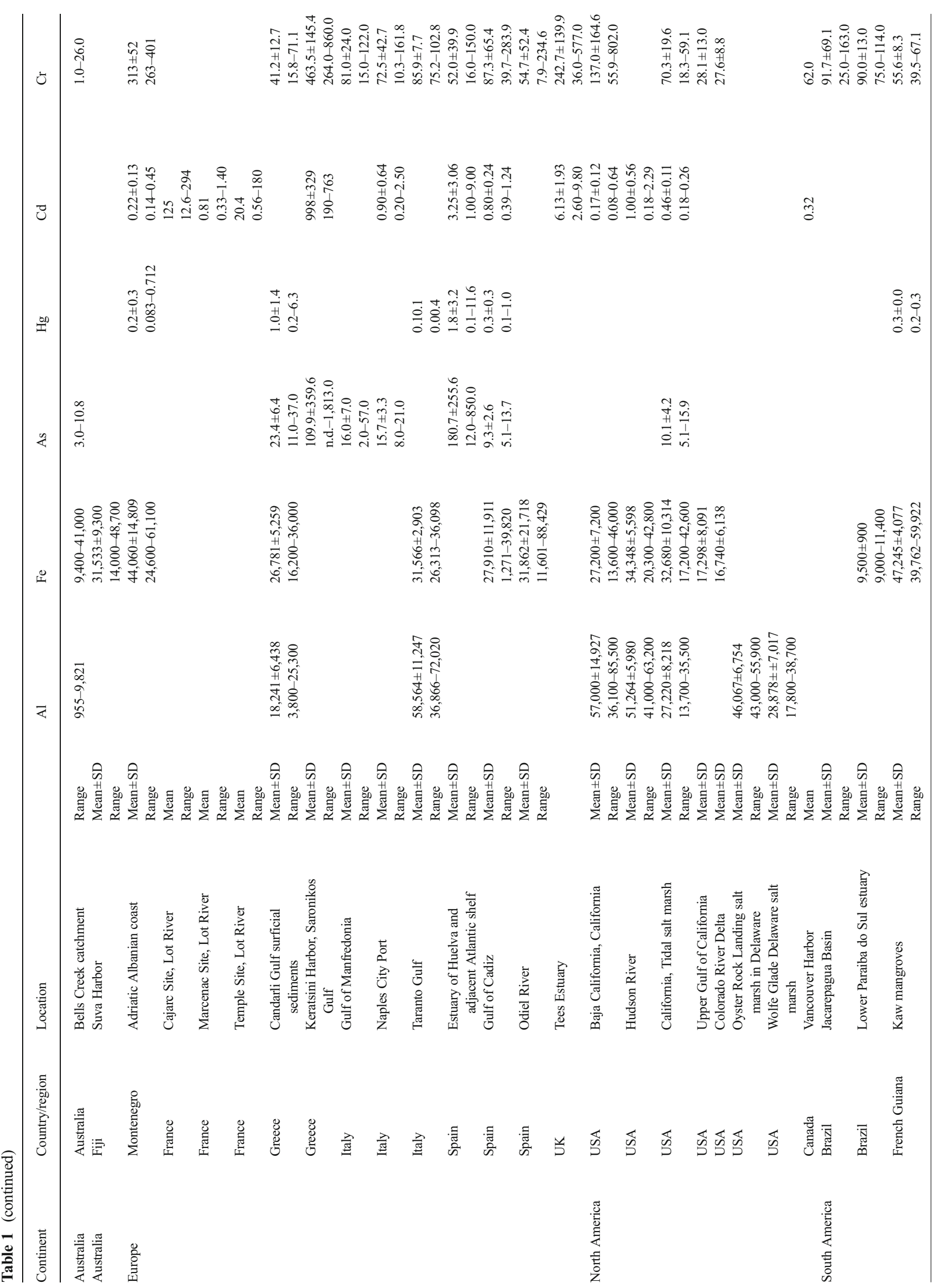




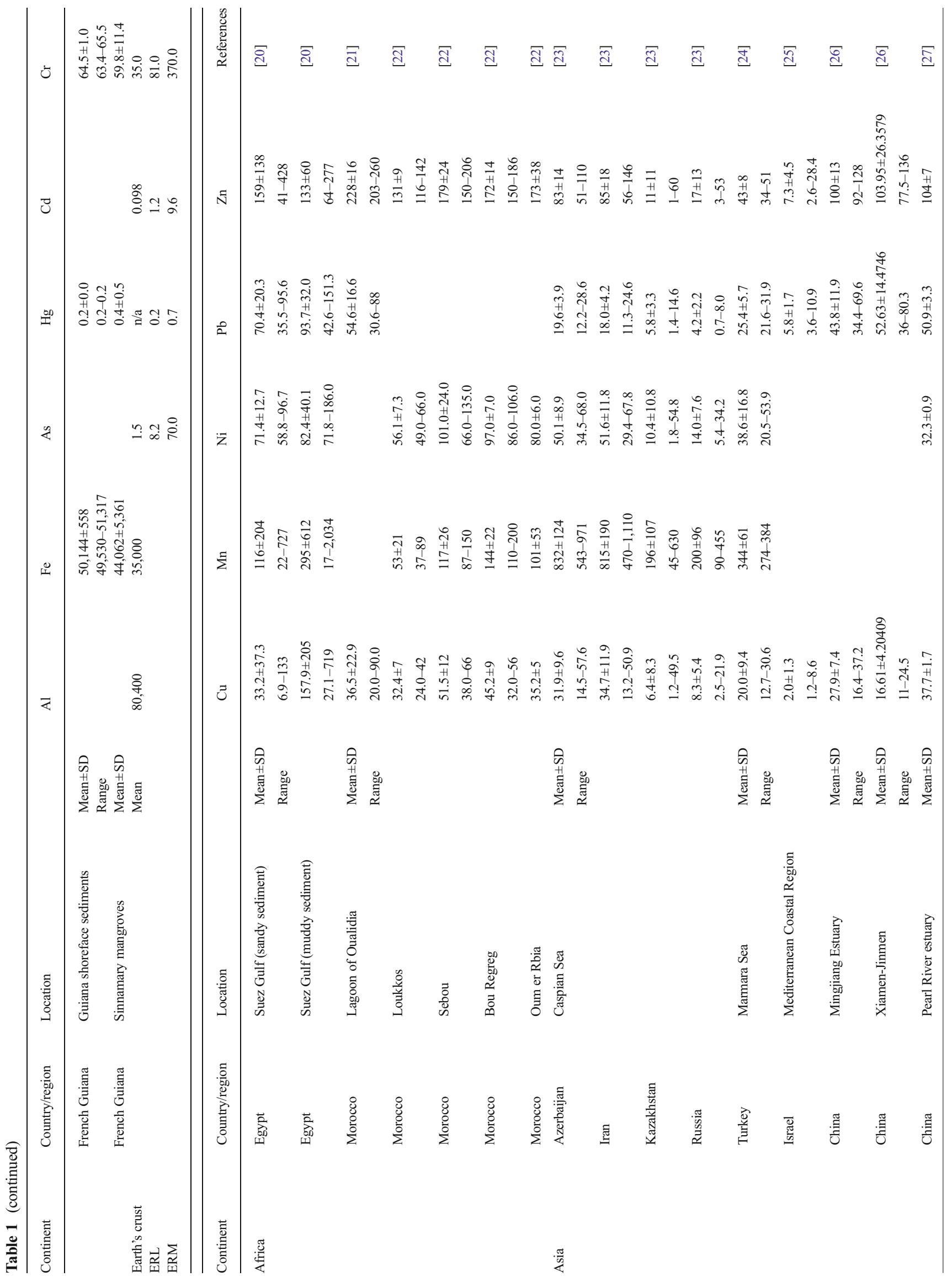




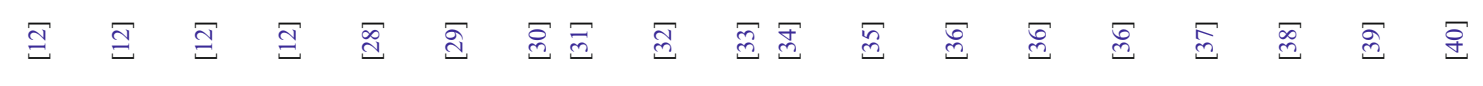

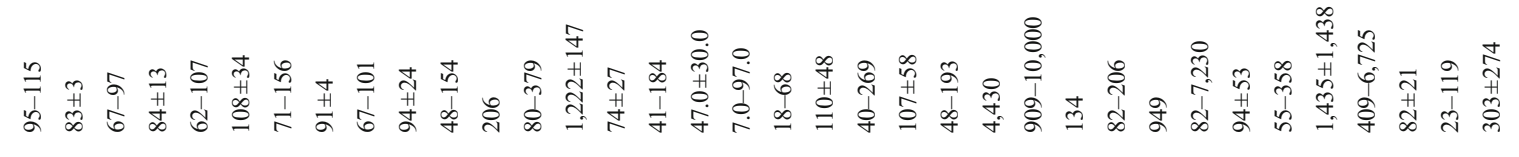

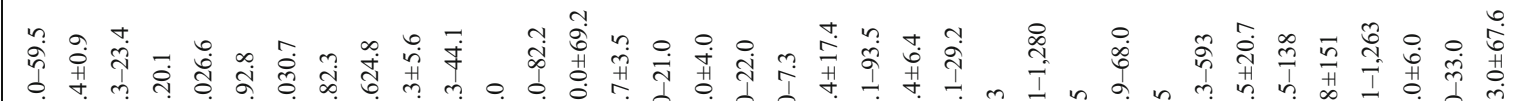

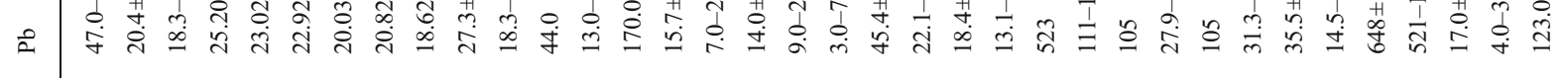

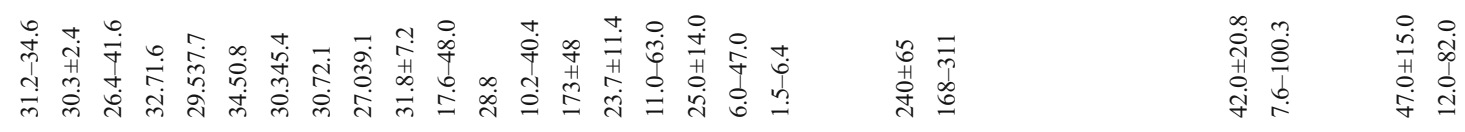

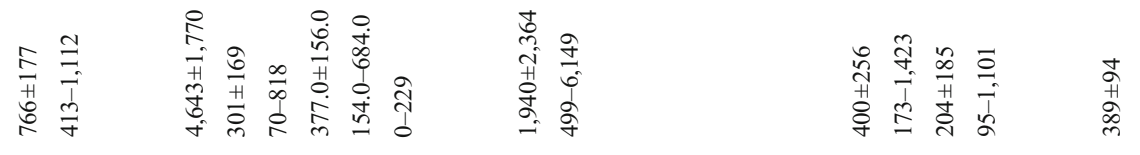

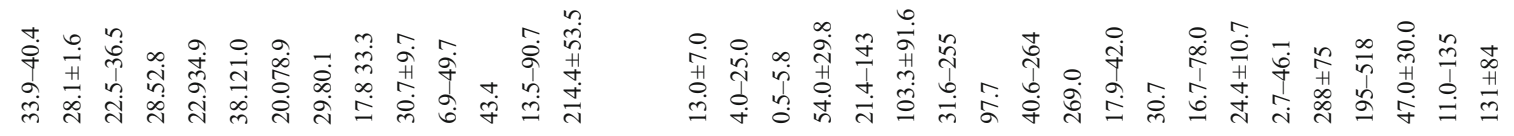

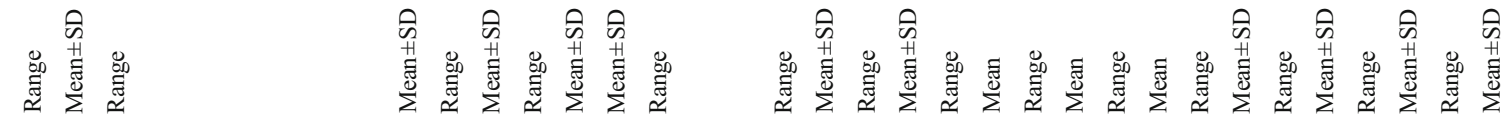




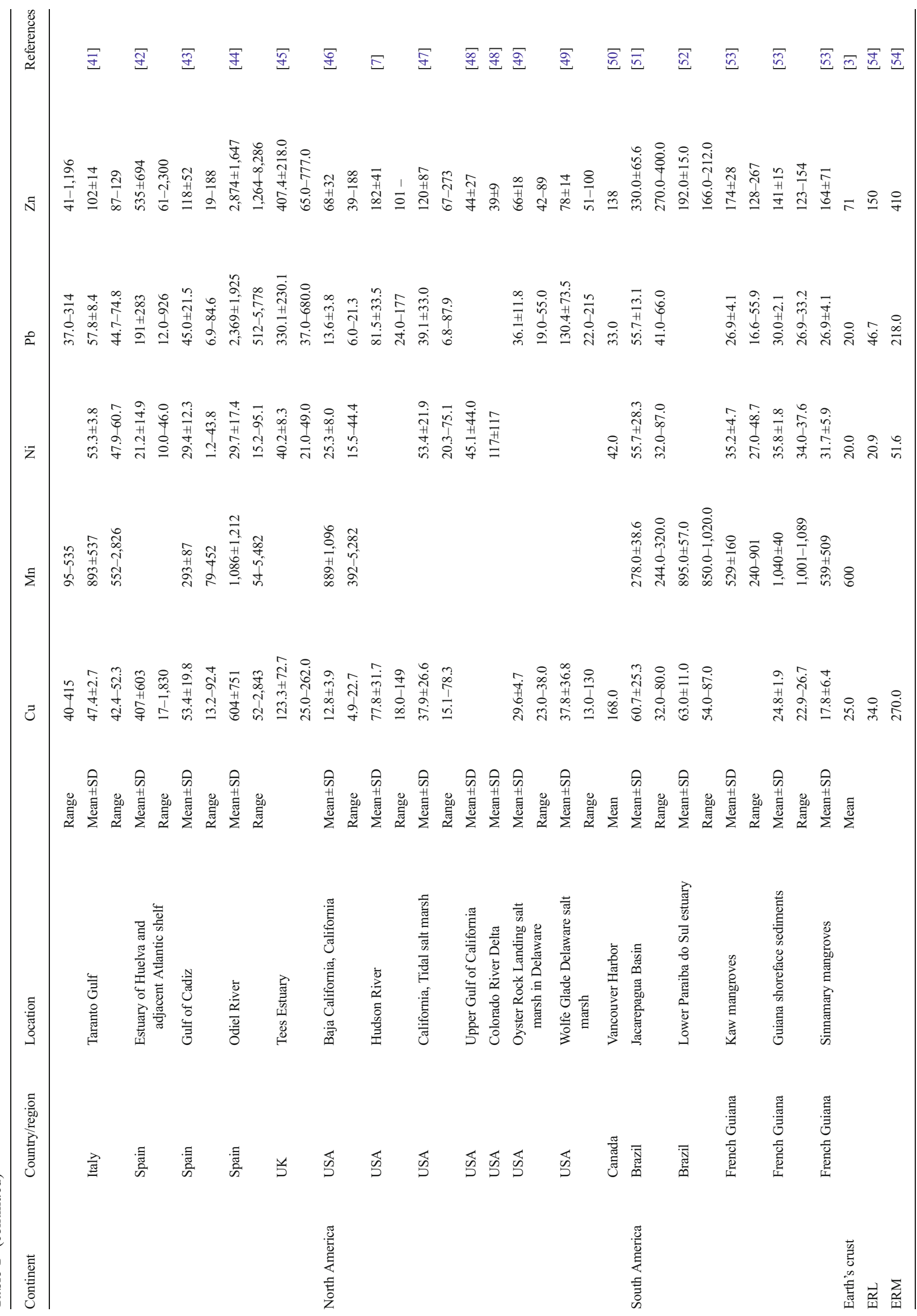




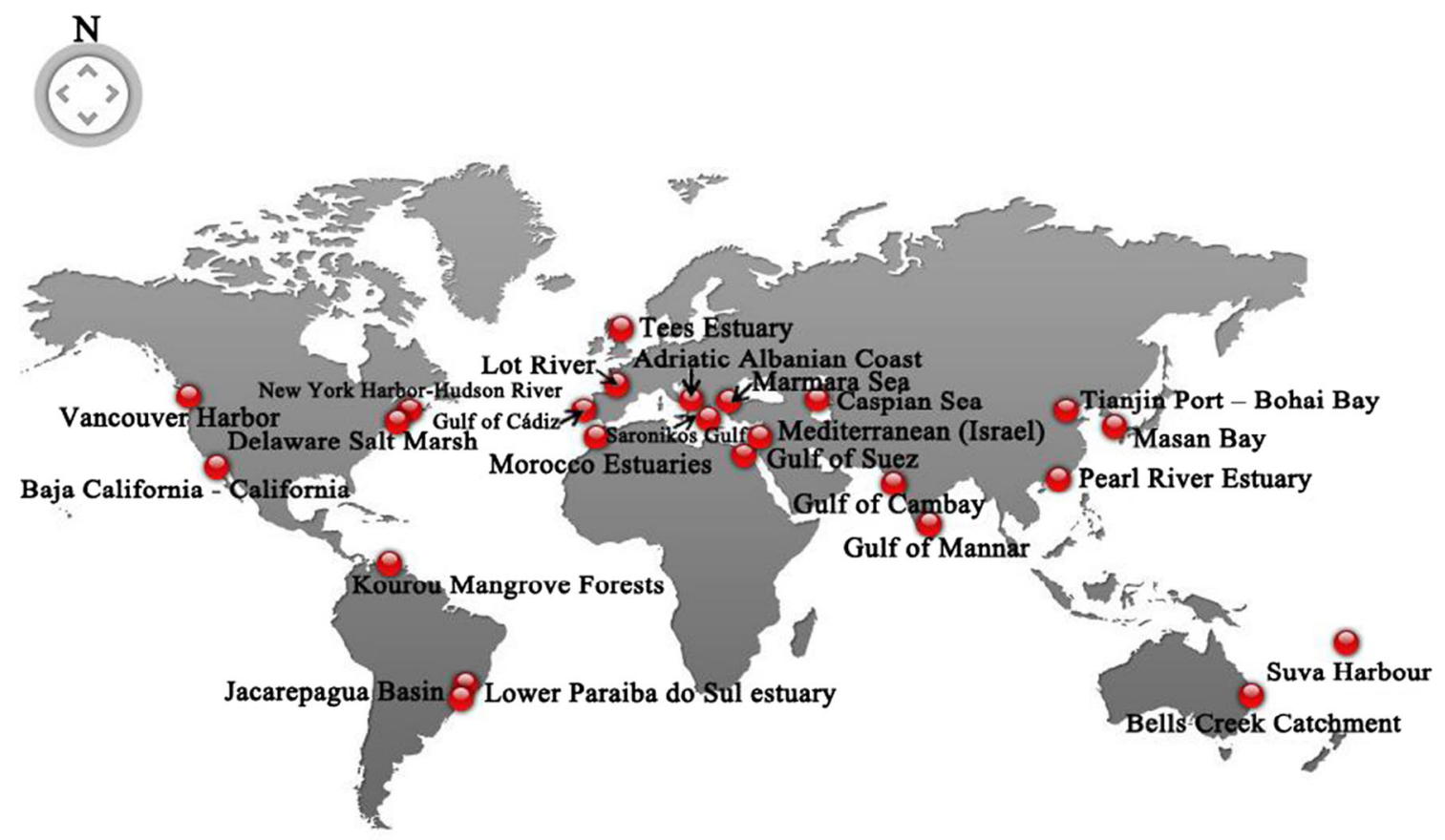

Fig. 1 Selected sites of estuaries and coastal areas worldwide

percentages of enrichment occur to As (100\%), Cd (73\%), Ni (58\%), and $\mathrm{Cr}(55 \%)$. The results show that metal EFs reflect the impact of external metal sources on the sediment quality. Metal enrichment among the selected coastal areas is shown in Fig. 2 and summarized below:

1. As - Barents Sea surface sediments (Russia) and Candarli Gulf (Greece) show extremely high enrichment of As (EF $>40$ ), and Caspian Sea, Gulf of Cadiz (Spain), Bells Creek catchment (Australia), and California tidal salt marsh (USA) show significant enrichment of As $(5<\mathrm{EF}<20)$.

2. Cd-Suez Gulf (Egypt), Alang-Sosiya coast intertidal zone (India), Oum er Rbia (Morocco), and Mediterranean Coastal Region (Israel) show extremely high enrichment of Cd (EF>40). Sebou (Morocco), Bou Regreg (Morocco), and Loukkos (Morocco) show very high enrichment of Cd $(20<\mathrm{EF}<40)$. Marmara Sea (Turkey), Hudson River (USA), Gulf of Cadiz (Spain), Masan Bay (Korea), Gulf of Mannar (India), and California tidal salt marsh (USA) show significant enrichment of $\mathrm{Cd}(5<\mathrm{EF}<20)$. Caspian Sea (Russia) and Yangtze River intertidal zone (China) show moderate enrichment $(2<\mathrm{EF}<5)$ of $\mathrm{Cd}$.

3. $\mathrm{Cr}-$ Gulf of Mannar (India), Suez Gulf (Egypt), Lower Paraiba do Sul estuary (Brazil), and Adriatic Albanian coast (Montenegro) show significant enrichment $(5<\mathrm{EF}$ $<20$ ) of Cr. Caspian Sea, Marmara Sea (Turkey), Gulf of Cadiz (Spain), Taranto Gulf (Italy), Yangtze River intertidal zone (China), Barents Sea (Russia), California tidal salt marsh (USA), and Alang-Sosiya coast intertidal zone (India) show moderate enrichment $(2<\mathrm{EF}<5)$ of $\mathrm{Cr}$.
4. $\mathrm{Cu}-$ Suez Gulf (Egypt) and Odiel River (Spain) show very high enrichment of $\mathrm{Cu}(20<\mathrm{EF}<40)$. Lower Paraiba do Sul estuary (Brazil) shows significant enrichment $(5<$ $\mathrm{EF}<20$ ) of Cu. Oum er Rbia (Morocco), Adriatic Albanian coast (Montenegro), Hudson River (USA), Gulf of Cadiz (Spain), Marmara Sea (Turkey), Sebou (Morocco), Suva Harbor (Fiji), Loukkos (Morocco), Alang-Sosiya coast intertidal zone (India), Caspian Sea (Russia), and Taranto Gulf (Italy) show moderate enrichment $(2<\mathrm{EF}<$ 5) of $\mathrm{Cu}$.

5. Mn-Lower Paraiba do Sul estuary (Brazil) shows significant enrichment $(5<\mathrm{EF}<20)$ of Mn (Fig. 2). Suez Gulf (Egypt), Adriatic Albanian coast (Montenegro), and Caspian Sea (Russia) show moderate enrichment $(2<\mathrm{EF}$ $<5)$ of $\mathrm{Mn}$.

6. Ni-Suez Gulf sandy sediment (Egypt) shows very high enrichment $(20<E F<40)$ of Ni. Suez Gulf muddy sediment of (Egypt), Colorado River Delta (USA), Oum er Rbia (Morocco), Adriatic Albanian coast (Montenegro), Marmara Sea (Turkey), Sebou (Morocco), and Bou Regreg (Morocco) show significant enrichment $(5<\mathrm{EF}<$ 20) of Ni (Fig. 2). Loukkos (Morocco), Upper Gulf of California (USA), Caspian Sea (Russia), Gulf of Mannar (India), Taranto Gulf (Italy), tidal salt marsh in California (USA), Candarli Gulf surficial sediments (Greece), Caspian Sea (Kazakhstan), Caspian Sea (Iran), Caspian Sea (Azerbaijan), and Alang-Sosiya coast intertidal (India) show moderate enrichment $(2<\mathrm{EF}<5)$ (Fig. 2).

7. $\mathrm{Pb}-$ Odiel River (Spain) and sandy sediment of Suez Gulf (Egypt) show extremely high enrichment $(\mathrm{EF}>40)$ of Pb. Muddy sediment of Suez Gulf (Egypt) shows very 

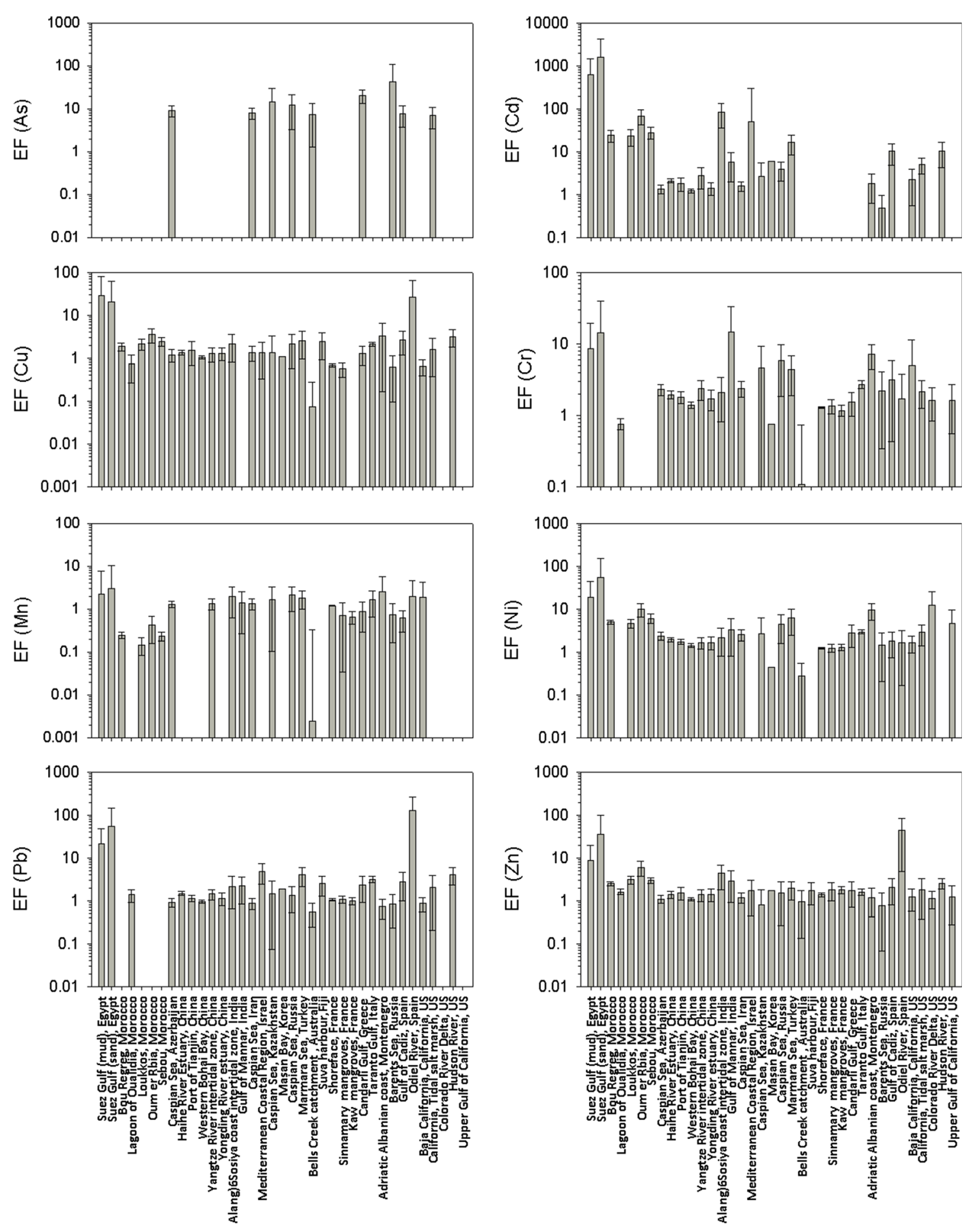

Location

Location

Fig. 2 Wide variations of metal $(\mathrm{Cd}, \mathrm{Cr}, \mathrm{Cu}, \mathrm{Ni}, \mathrm{Pb}$, and $\mathrm{Zn})$ enrichment factors ( $\mathrm{EF})$ reflect different sources and enrichment levels of metals in the sediments from different regions. High enrichment $(\mathrm{EF}>2)$ suggests various degrees of metal pollution

high enrichment $(20<\mathrm{EF}<40)$ of $\mathrm{Pb}$. Mediterranean Coastal Region (Israel), Hudson River (USA), Marmara Sea (Turkey), Taranto Gulf (Italy), Gulf of Cadiz (Spain), Suva Harbor (Fiji), Candarli Gulf surficial sediments (Greece), Gulf of Mannar (India), Alang-Sosiya coast intertidal (India), and California tidal salt marsh (USA) show moderate enrichment $(2<\mathrm{EF}<5)$ of $\mathrm{Pb}$.

8. $\mathrm{Zn}$ - Odiel River (Spain) shows extremely high enrichment $(E F>40)$ of Zn. Suez Gulf sandy sediment (Egypt) shows very high enrichment $(20<\mathrm{EF}<40)$ of $\mathrm{Zn}$. Lower 
Table 2 Percentage of coastal areas that have different degrees fo potential contamination caused by $\mathrm{As}, \mathrm{Cd}, \mathrm{Cr}, \mathrm{Cu}, \mathrm{Mn}, \mathrm{Ni}, \mathrm{Pb}$ and/Zn

\begin{tabular}{|c|c|c|c|c|c|c|c|}
\hline \multirow[t]{2}{*}{ Elements } & \multirow{2}{*}{$\begin{array}{l}\text { Total cases } \\
\text { (n) }\end{array}$} & \multicolumn{5}{|c|}{ Percentage of coastal areas with EF values of } & \multirow[t]{2}{*}{ Tota } \\
\hline & & $<2$ & $2 \sim 5$ & $5 \sim 20$ & $20 \sim 40$ & $>40$ & \\
\hline As & 9 & 0.0 & 0.0 & 77.8 & 11.1 & 11.1 & 100 \\
\hline $\mathrm{Cd}$ & 26 & 26.9 & 23.1 & 19.2 & 11.5 & 19.2 & 100 \\
\hline $\mathrm{Cr}$ & 31 & 45.2 & 32.3 & 22.6 & 0.0 & 0.0 & 100 \\
\hline $\mathrm{Cu}$ & 34 & 55.9 & 32.4 & 2.9 & 8.8 & 0.0 & 100 \\
\hline $\mathrm{Mn}$ & 26 & 80.8 & 15.4 & 3.9 & 0.0 & 0.0 & 100 \\
\hline $\mathrm{Ni}$ & 33 & 42.4 & 30.3 & 18.2 & 6.1 & 3.0 & 100 \\
\hline $\mathrm{Pb}$ & 31 & 58.1 & 32.3 & 0.0 & 3.2 & 6.5 & 100 \\
\hline $\mathrm{Zn}$ & 38 & 68.4 & 18.4 & 7.9 & 2.6 & 2.6 & 100 \\
\hline
\end{tabular}

Five categories of metal enrichment are defined based on metal enrichment factor $(\mathrm{EF})$ : 1$)$ deficiency to minimal enrichment $(\mathrm{EF}<2)$, 2$)$ moderate enrichment $(E F=2-5), 3)$ significant enrichment $(E F=5-20), 4)$ very high enrichment $(E F=20-40)$, and 5) extremely high enrichment $(E F>40)$

Paraiba do Sul estuary (Brazil), Suez Gulf muddy sediment (Egypt), and Oum er Rbia (Morocco) show significant enrichment $(5<\mathrm{EF}<20)$ of $\mathrm{Zn}$. Alang-Sosiya coast intertidal (India), Loukkos (Morocco), Sebou (Morocco), Gulf of Mannar (India), Hudson River (USA), Bou Regreg (Morocco), and Gulf of Cadiz (Spain) show moderate enrichment $(2<\mathrm{EF}<5)$ of $\mathrm{Zn}$ (Fig. 2).

\section{Metal Pollution and Ecological Impact}

Ecotoxicity and biogeochemical circulation of metals in an ecosystem are determined by the metal concentration that organisms are exposed to. When the metal concentration in sediment exceeds certain threshold level, adverse biological effects frequently occur. At molecular level, excessive metal accumulation in the organism might stimulate biological counter stress processes such as induction of antioxidant enzymes, physiological impairment, and extra energy consumption [75]. As a result, organism mortality rises continuously when sediment metal concentrations increase [54].

To avoid adverse ecological effects from sediments, several approaches have been developed to assess the metal hazard potential to organisms as guidance for coastal ecosystem protection and restoration $[54,76,77]$. Generally, the potential ecotoxicological risk of metals on organisms in the sediments can be evaluated using the sediment guidelines (e.g., [54, 76, 78-80]). In order to better predict the toxicity of contaminants, Long et al. [54] defined the effect range-low (ERL) and effect range-median (ERM) system based on the compilation of matching biological and chemical data from numerous modeling, laboratory, and field measurement in marine and estuarine sediments. According to Long et al. [54], ERL is defined based on the concentration when 10th percentiles of organisms are influenced by the toxicity of a specific contaminant, while ERM value is decided when 50th percentiles of organisms are influenced by the toxicity of the contaminant in that concentration. Three effect ranges of contaminant level could be set up based on ERL and ERM. When the contaminant concentration is below ERL, a very rare biological adverse effect is anticipated, and when the concentration is between ERL and ERM, an occasional biological adverse effect is expected. However, when the concentration is greater than ERM value, a frequent biological adverse effect ( $>50 \%$ chances) could occur $[54,76,78]$. To evaluate the potential biological adverse effect, hazard quotient (HQ) is one kind of singlevalue estimate and is also the simplest method to estimate toxicity potential of the selected pollutants in the sediments [77, 81]. According to Urban and Cook [77], the HQ is defined as

$\mathrm{HQ}=\frac{\mathrm{SCC}}{\mathrm{SQG}}$

where SCC is the sediment chemical concentration and SQG stands for the concentration defined by the sediment quality guideline. Both SCC and SQG are in milligram per kilogram. Since ERL is more reasonably predictive of non-toxic condition (SQGs), the $\mathrm{SQG}$ is set at ERL levels: $\mathrm{Cd}=1.2, \mathrm{Cr}=81$, $\mathrm{Cu}=34, \mathrm{Ni}=20.9, \mathrm{~Pb}=46.7$, and $\mathrm{Zn}=150$ [54]. If $\mathrm{HQ}<0.1$, no adverse effects are expected; if $0.1<\mathrm{HQ}<1$, low potential hazards are expected; in the range of $1.0<\mathrm{HQ}<10$, some adverse effects or moderate hazards are probable; and when $\mathrm{HQ}>10$, high hazard potential is anticipated $[81,82]$.

As showed in Fig. 3, HQ values calculated from the average metal concentrations in the selected coastal sediments range from 0.36 to 22 for $\mathrm{As}(n=13), 0.03$ to 832 for $\mathrm{Cd}$ $(n=36), 0.01$ to 6 for $\mathrm{Cr}(n=38), 0.01$ to 18 for $\mathrm{Cu}(n=49)$, 0.07 to 12 for $\mathrm{Hg}(n=12), 0.01$ to 12 for $\mathrm{Ni}(n=36), 0.06$ to 51 for $\mathrm{Pb}(n=49)$, and 0.05 to 30 for $\mathrm{Zn}(n=53)$. The percentages of the coastal areas facing various degree of hazard potential from no adverse effects $(\mathrm{HQ}<0.1)$ to high hazard potential 

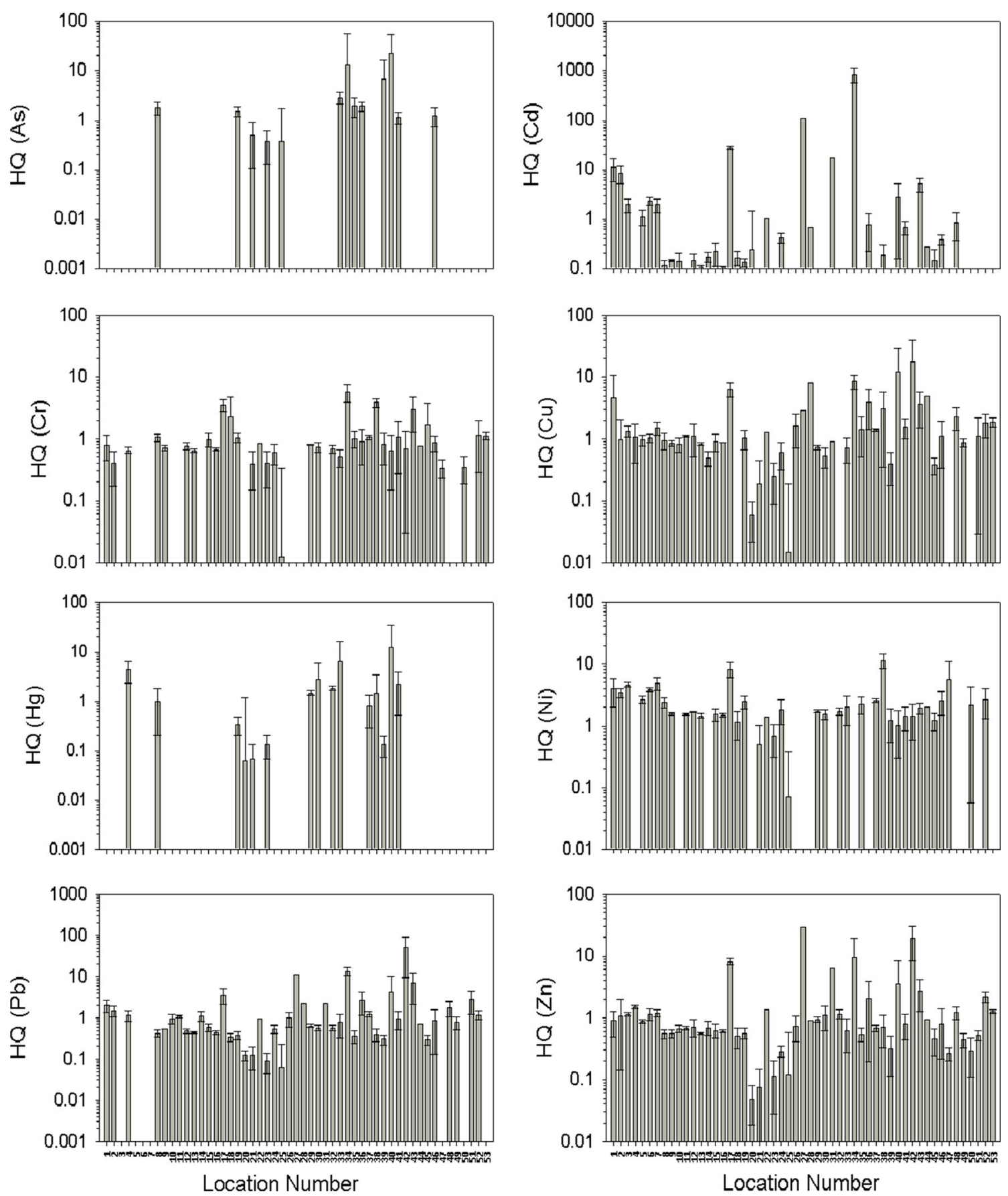

Fig. 3 Hazard quotients (HQ) of $\mathrm{Cd}, \mathrm{Cr}, \mathrm{Cu}, \mathrm{Ni}, \mathrm{Pb}$, and $\mathrm{Zn}$ in the sediments from the selected coastal areas. Moderate $(1<\mathrm{HQ}<10)$ to high $(\mathrm{HQ}>10)$ hazard potential that can cause adverse biological effect are anticipated in some coastal areas. Location numbers: 1 Suez Gulf (mud), Egypt; 2 Suez Gulf (sand), Egypt; 3 Bou Regreg, Morocco; 4 Lagoon of Oualidia, Morocco; 5 Loukkos, Morocco; 6 Oum er Rbia, Morocco; 7 Sebou, Morocco; 8 Caspian Sea, Azerbaijan; 9 Haihe River Estuary, China; 10 Mingjiang Estuary, China; 11 Pearl River estuary, China; 12 Port of Tianjin, China; 13 Western Bohai Bay, China; 14 Xiamen-Jinmen, China; 15 Yangtze River intertidal zone, China; 16 Yongding River estuary, China; 17 Alang-Sosiya coast intertidal zone, India; 18 Gulf of Mannar, India; 19 Caspian Sea, Iran; 20 Mediterranean Coastal Region, Israel; 21 Caspian Sea, Kazakhstan; 22 Masan Bay, Korea; 23 Caspian Sea, Russia; 24 Marmara Sea, Turkey; 25 Bells Creek

catchment, Australia; 26 Suva Harbor, Fiji; 27 Cajarc Site, Lot River, France; 28 Marcenac Site, Lot River, France; 29 Shoreface, France; 30 Sinnamary mangroves, France; 31 Temple Site, Lot River, France; 32 Kaw mangroves, France; 33 Candarli Gulf, Greece; 34 Keratsini Harbor, Saronikos Gulf, Greece; 35 Gulf of Manfredonia, Italy; 36 Naples City Port, Italy; 37 Taranto Gulf, Italy; 38 Adriatic Albanian coast, Montenegro; 39 Barents Sea, Russia; 40 Estuary of Huelva and adjacent Atlantic shelf, Spain; 41 Gulf of Cadiz, Spain; 42 Odiel River, Spain; 43 Tees Estuary, UK; 44 Vancouver Harbor, Canada; 45 Baja California, California, USA; 46 California, Tidal salt marsh, US; 47 Colorado River Delta, US; 48 Hudson River, USA; 49 Oyster Rock Landing salt marsh in Delaware, USA; 50 Upper Gulf of California, US; 51 Wolfe Glade Delaware salt marsh, USA; 52 Jacarepagua Basin, Brazil; 53 Lower Paraiba do Sul estuary, Brazil 
$(\mathrm{HQ}>10)$ are shown in Table 3 . In most of the areas, only low hazard potentials $(0.1<\mathrm{HQ}<1)$ are expected. However, As $(15 \%)$ and $\mathrm{Cd}(14 \%)$ show relative high percentage in hazard potentials $(\mathrm{HQ}>10)$ (Table 3$)$. The potential adverse biological effects caused by each individual metal are summarized below:

1. As-High hazard potential $(\mathrm{HQ}>10)$ caused by As is anticipated in Estuary of Huelva and adjacent Atlantic shelf (Spain) and Keratsini Harbor, Saronikos Gulf (Greece); moderate hazard potential $(1<\mathrm{HQ}<10)$ in Barents Sea (Russia), Candarli Gulf (Greece), Gulf of Manfredonia (Italy), Naples City Port (Italy), Caspian Sea (Iran and Kazakhstan), California tidal salt marsh (USA), and Gulf of Cadiz (Spain); and low hazard potential $(0.1<\mathrm{HQ}<1)$ in Caspian Sea (Kazakhstan and Russia) and Bells Creek catchment (Australia) (Fig. 3).

2. Cd-High hazard potential $(\mathrm{HQ}>10)$ caused by $\mathrm{Cd}$ is anticipated in Keratsini Harbor, Saronikos Gulf (Greece), Cajarc Site, Lot River (France), Alang-Sosiya coast intertidal zone (India), Temple Site, Lot River (France), and Suez Gulf muddy sediment (Egypt); moderate hazard potential $(1<\mathrm{HQ}<10)$ in Suez Gulf (Egypt), Tees Estuary (UK), Estuary of Huelva and adjacent Atlantic shelf (Spain), Oum er Rbia (Morocco), Sebou (Morocco), Bou Regreg (Morocco), Loukkos (Morocco), and Masan Bay (Korea); and low hazard potential $(0.1<\mathrm{HQ}<1)$ in Hudson River (USA), Naples City Port (Italy), Marcenac Site, Lot River (France), Gulf of Cadiz (Spain), Marmara Sea (Turkey), California tidal salt marsh (USA), Vancouver Harbor (Canada), Mediterranean Coastal Region (Israel), Yangtze River intertidal zone (China), Adriatic Albanian coast (Montenegro), Xiamen-Jinmen (China), Gulf of Mannar (India), Port of Tianjin (China), Haihe River Estuary (China), Baja California (USA), Mingjiang Estuary (China), Caspian Sea (Iran and Azerbaijan), Western Bohai Bay (China), and Yongding River estuary (China).
3. $\mathrm{Cr}$-Moderate hazard potential $(1<\mathrm{HQ}<10)$ caused by $\mathrm{Cr}$ is anticipated in Keratsini Harbor (Greece), Adriatic Albanian coast (Montenegro), Alang-Sosiya coast intertidal (India), Tees Estuary (UK), Gulf of Mannar (India), Baja California (USA), Jacarepagua Basin (Brazil), Lower Paraiba do Sul estuary (Brazil), Gulf of Cadiz (Spain), Taranto Gulf (Italy), Caspian Sea (Azerbaijan), and Caspian Sea (Iran); low hazard potential $(0.1<\mathrm{HQ}<1)$ in Gulf of Manfredonia (Italy), Yangtze River intertidal (China), Naples City Port (Italy), California tidal salt marsh (USA), Masan Bay (Korea), Barents Sea (Russia), Guiana shoreface sediments (France), Suez Gulf muddy sediment (Egypt), Port of Tianjin (China), Vancouver Harbor (Canada), Sinnamary mangroves (France), Haihe River Estuary (China), Kaw mangroves (France), Odiel River (Spain), Lagoon of Oualidia (Morocco), Western Bohai Bay (China), Estuary of Huelva and adjacent Atlantic shore (Spain), Marmara Sea (Turkey), Candarli Gulf (Greece), Suez Gulf sandy sediment (Egypt), Caspian Sea (Russia), Caspian Sea (Kazakhstan), Upper Gulf of California (USA), and Colorado River Delta (USA).

4. $\mathrm{Cu}-$ High hazard potential $(\mathrm{HQ}>10)$ caused by $\mathrm{Cu}$ is anticipated in Odiel River (Spain) and Estuary of Huelva (Spain); moderate hazard potential $(1<\mathrm{HQ}<10)$ in Keratsini Harbor (Greece), Marcenac Site (France), Alang-Sosiya coast intertidal (India), Vancouver Harbor (Canada), Suez Gulf muddy sediment (Egypt), Naples City Port (Italy), Tees Estuary (UK), Adriatic Albanian coast (Montenegro), Cajarc Site in Lot River (France), Hudson River (USA), Lower Paraiba do Sul estuary (Brazil), Jacarepagua Basin (Brazil), Suva Harbor (Fiji), Gulf of Cadiz (Spain), Sebou (Morocco), Taranto Gulf (Italy), Gulf of Manfredonia (Italy), Bou Regreg (Morocco), Masan Bay (Korea), Port of Tianjin (China), California tidal salt marsh (USA), Wolfe Glade Delaware salt marsh (USA), Pear River estuary (China), Lagoon of Oualidia
Table 3 Percentage of coastal areas that have potential adverse effects caused by $\mathrm{As}, \mathrm{Cd}, \mathrm{Cr}, \mathrm{Cu}$, $\mathrm{Hg}, \mathrm{Ni}, \mathrm{Pb}$ and/Zn

\begin{tabular}{lllllll}
\hline Elements & Total cases & \multicolumn{5}{l}{ Percentage of coastal areas with HQ values of } \\
\cline { 3 - 7 } & $(n)$ & $<0.1$ & $0.1<\mathrm{HQ}<1$ & $1.0<\mathrm{HQ}<10$ & $\mathrm{HQ}>10$ & Total \\
\hline $\mathrm{As}$ & 13 & 0.0 & 23.1 & 61.5 & 15.4 & 100 \\
$\mathrm{Cd}$ & 36 & 8.3 & 55.6 & 22.2 & 13.9 & 100 \\
$\mathrm{Cr}$ & 37 & 2.7 & 64.9 & 32.4 & 0.0 & 100 \\
$\mathrm{Cu}$ & 49 & 4.1 & 38.8 & 53.1 & 4.1 & 100 \\
$\mathrm{Hg}$ & 12 & 8.3 & 25.0 & 58.3 & 8.3 & 100 \\
$\mathrm{Ni}$ & 39 & 2.6 & 5.1 & 89.7 & 2.6 & 100 \\
$\mathrm{~Pb}$ & 46 & 4.4 & 56.5 & 32.6 & 6.5 & 100 \\
$\mathrm{Zn}$ & 53 & 3.8 & 60.4 & 32.1 & 3.8 & 100 \\
\hline
\end{tabular}

The hazardous quotient value (HQ) suggests no adverse effects $(\mathrm{HQ}<0.1)$, low adverse effects $(0.1<\mathrm{HQ}<1)$, moderate adverse effects $(1.0<\mathrm{HQ}<10)$, or high adverse effects $(\mathrm{HQ}>10)$ 
(Morocco), Oum er Rbia (Morocco), and Caspian Sea (Iran); and low hazard potential $(0.1<\mathrm{HQ}<1)$ in Suez Gulf sandy sediment (Egypt), Loukkos (Morocco), Caspian Sea (Azerbaijan), Yangtze River intertidal (China), Lot River Temple site (France), Oyster Rock Landing salt marsh in Delaware (USA), Haihe River Estuary (China), Western Bohai Bay (China), Mingjiang Estuary (China), Guiana shoreface sediments (France), Candarli Gulf surficial sediments (Greece), Marmara Sea (Turkey), Sinnamary mangroves (France), Xiamen-Jinmen (China), Barents Sea (Russia), Baja California (USA), Caspian Sea (Russia), and Caspian Sea (Kazakhstan). Hg-High hazard potential $(\mathrm{HQ}>10)$ caused by $\mathrm{Hg}$ is anticipated in Estuary of Huelva and adjacent Atlantic shelf (Spain); moderate hazard potential $(1<\mathrm{HQ}<10)$ in Candarli Gulf (Greece), Lagoon of Oualidia (Morocco), Sinnamary mangroves (France), Gulf of Cadiz (Spain), Kaw mangroves (France), Guiana shoreface sediments (France), and Adriatic Albanian coast (Montenegro); low hazard potential $(0.1<\mathrm{HQ}<1)$ in Caspian Sea and Barents Sea (Russia) (Fig. 3).

5. Ni-High hazard potential $(\mathrm{HQ}>10)$ caused by $\mathrm{Ni}$ is anticipated in Adriatic Albanian coast (Montenegro); moderate hazard potential $(1<\mathrm{HQ}<10)$ in Alang-Sosiya coast intertidal (India), Colorado River Delta (USA), Sebou (Morocco), Bou Regreg (Morocco), Suez Gulf muddy sediment (Egypt), Oum er Rbia (Morocco), Suez Gulf sandy sediment (Egypt), Loukkos (Morocco), Jacarepagua Basin (Brazil), California tidal salt marsh (USA), Taranto Gulf (Italy), Caspian Sea (Iran), Caspian Sea (Azerbaijan), Gulf of Manfredonia (Italy), Upper Gulf of California (USA), Candarli gulf surficial sediments (Greece), Vancouver Harbor (Canada), Tees Estuary (UK), Marmara Sea (Turkey), Guiana shoreface sediments (France), Kaw mangroves (France), Port of Tianjin (China), Haihe River Estuary (China), Pearl River estuary (China), Yangtze River intertidal (China), Sinnamary mangroves (France), Western Bohai Bay (China), Odiel River (Spain), Gulf of Cadiz (Spain), Masan Bay (Korea), Baja California (USA), Barents Sea surface sediments (Russia), Gulf of Mannar (India), and Estuary of Huelva (Spain); low hazard potential $(0.1<\mathrm{HQ}<1)$ in Caspian Sea (Russia), Caspian Sea (Kazakhstan), and Estuary of Huelva and adjacent (Spain).

6. $\mathrm{Pb}-$ High hazard potential $(\mathrm{HQ}>10)$ caused by $\mathrm{Pb}$ is anticipated in Odiel River (Spain), Keratsini Harbor (Greece), and Lot River Cajarc site (France); moderate hazard potential $(1<\mathrm{HQ}<10)$ in Tees Estuary (UK), Estuary of Huelva (Spain), Alang-Sosiya coast intertidal (India), Wolfe Glade Delaware salt marsh (USA), Naples City Port (Italy), Lot River Marcenac site (France), Lot River Temple site (France), Suez Gulf muddy sediment (Egypt), Hudson River (USA), Suez Gulf sandy sediment
(Egypt), Taranto Gulf (Italy), Jacarepagua Basin (Brazil), Lagoon of Oualidia (Morocco), Xiamen-Jinmen (China), and Pearl River estuary (China); and low hazard potential $(0.1<\mathrm{HQ}<1)$ in Suva Harbor (Fiji), Gulf of Cadiz (Spain), Masan Bay (Korea), Mingjiang Estuary (China), California tidal salt marsh (USA), Oyster Rock Landing salt marsh (USA), Candarli Gulf surficial sediments (Greece), Vancouver Harbor (Canada), Guiana shoreface sediments (France), Yangtze River intertidal (China), Kaw mangroves (France), Sinnamary mangroves (France), Marmara Sea (Turkey), Haihe River Estuary (China), Port of Tianjing (China), Western Bohai Bay (China), Caspian Sea (Iran), Gulf of Manfredonia (Italy), Gulf of Mannar (India), Barents Sea (Russia), Baja California (USA), Mediterranean Coastal Region (Israel), and Caspian Sea (Kazakhstan).

7. $\mathrm{Zn}$ - High hazard potential $(\mathrm{HQ}>10)$ caused by $\mathrm{Zn}$ is anticipated in Lot River Cajarc Site (France) and Odiel River (Spain); moderate hazard potential $(1<\mathrm{HQ}<10)$ in Keratsini Harbor (Greece), Alang-Sosiya coast intertidal (India), Lot River Temple site (France), Estuary of Huelva (Spain), Tees Estuary (UK), Jacarepagua Basin (Brazil), Naples City Port (Italy), Lagoon of Oualidia (Morocco), Masan Bay (Korea), Lower Paraiba do Sul estuary (Brazil), Hudson River (USA), Sebou (Morocco), Kaw mangroves (France), Oum er Rbia (Morocco), Bou Regreg (Morocco), Sinnamary mangroves (France), and Suez Gulf sandy sediment (Egypt); and low hazard potential $(0.1<\mathrm{HQ}<1)$ in Guiana shoreface sediments (France), Vancouver Harbor (Canada), Lot River Marcenac site (France), Suez Gulf muddy sediment (Egypt), Loukkos (Morocco), California tidal salt marsh (USA), Gulf of Cadiz (Spain), Suva Harbor (Fiji), Port of Tianjin (China), Adriatic Albanian coast (Montenegro), Pearl River estuary (China), Xiamen-Jinmen (China), Taranto Gulf (Italy), Mingjiang Estuary (China), Yangtze River intertidal (China), Candarli Gulf surficial sediments (Greece), Caspian Sea (Iran), Haihe River Estuary (China), Western Hohai Bay (China), Caspian Sea (Azerbaijan), Gulf of Manfredonia (Italy), Wolfe Glade Delaware salt marsh (USA), Gulf of Mannar (India), Baja California (USA), Oyster Rock Landing salt marsh (USA), Barents Sea (Russia), Upper Gulf of California (USA), Marmara Sea (Turkey), Colorado River Delta (USA), Bells Creek Catchment (Australia), and Caspian Sea (Russia).

\section{Discussion}

Besides anthropogenic sources, metal accumulation and distribution in the estuary sediments are also influenced by the interaction between metals and sediments. Therefore, factors 
such as sediment grain size, sediment surface dynamic equilibrium, and exposure time can also influence the spatial accumulation of metals in marine sediments [7, 12, 46]. Among all the 52 sites summarized in this review, seven major coastal areas adjacent to highly industrialized and urbanized regions were chosen to further investigate the major factors determining metal accumulation and spatial distribution in costal sediments. These seven coastal areas including New York Harbor-Hudson River Estuary [7], Egypt Suez Gulf [20], China Tianjin Port-Bohai Bay [12], India Gulf of Cambay [30], Greece Saronikos Gulf [38], and Mexico Baja California and USA California Gulf [46] were selected because detailed information on the source and cause of metal distribution in sediments were provided by the authors. The major sources of metal contamination include upriver input (PCBs in Hudson River estuary), urban wastewater runoff (New York Harbor, Suez Gulf, Bohai Bay, Saronikos Gulf, and Baja California), port transportation (Tianjin Port and Saronikos Gulf), and industrial wastes (Suez Gulf, Gulf of Cambay, and Saronikos Gulf).

The enrichment level and spatial distribution of metals along the coastal area in the selected sites varied with contamination sources and the time of exposure. In the New York Harbor-Hudson River estuary coastal area, the distribution of metal in sediments was mainly influenced by upriver source, urban source, and sediment particle grain size. Silver was identified as tracer of urban source contamination based on correlation analysis [7] (Fig. 1). The sandy and muddy sediments in Gulf of Suez were analyzed separately, and metal concentrations were different between the two because their capacities to adsorb metals from water were different. In addition, metals in the sediments showed three different accumulation clusters $(\mathrm{Cr}, \mathrm{Cu}, \mathrm{Fe}$, and $\mathrm{Mn} ; \mathrm{Cd}$ and $\mathrm{Pb}$; and $\mathrm{Co}$ ), possibly because the metals were from various contamination sources such as offshore oil fields, industrial wastes, and ballast water [30] (Fig. 1). In Tianjin Port-Bohai Bay coastal area, high metal enrichment was mostly observed in sediments collected in Tianjin Port. ${ }^{210} \mathrm{~Pb}$ analysis indicated that metal concentrations were increasing in the recent years, suggesting that the contaminants were continuously released into the coastal area while the further transportation of contaminants into Bohai Bay was limited [12] (Fig. 1). Among all the coastal sites investigated, the Alang-Sosiya yard in the Gulf of Cambay has the highest metal contamination level. In addition, metal concentrations in the sediment close to the ship scrapping workshop were much higher than that in the sediment collected in the gulf intertidal zone, which was only $0.5 \mathrm{~km}$ from the ship scrapping workshop. It can be indicated that the ship scrapping industry and the domestic waste charge along it is possibly the main source of metal in the sediment. Moreover, metal concentrations in the bulk sediment lower than that in the fine sediment confirmed that metals were more bounded to the fine fraction of sediment due to its larger surface area [30] (Fig. 1). Greece Saronikos Gulf is another port that is heavily influenced by port transportation. However, compared to Tianjin Port, the level of metal enrichment was relatively high. This is possibly due to the discharge of sewage outfall into the gulf from the adjacent highly industrialized areas [38] (Fig. 1). Finally, the spatial variation of metal accumulated in the USA-Mexico (Baja California-California) estuary varied with the anthropogenic activities along the seashore. Among the 19 sampling sites that ranged from Pt. Loma Wastewater Treatment Plant in San Diego (USA) to Punta Bandera Treatment Plant in Tijuana (Mexico), sites close to Punta Bandera had higher concentration of $\mathrm{Cu}, \mathrm{Zn}$, $\mathrm{Ni}$, and $\mathrm{Cr}$. At the same time, $\mathrm{Cd}, \mathrm{Ag}$, and $\mathrm{Pb}$ showed different accumulation pattern, indicating a different metal discharge source other than Punta Bandera Treatment plant [46] (Fig. 1).

Finally, the dynamic biogeochemical circulation and accumulation of metals in sediments are also affected by the ecotoxicity of metals in sediments. The dynamic physiochemical ecological processes that mediated the transportation of substances within the ecosystem can redistribute the accumulation of metals in coastal sediments by concentrating, permanently depositing, and transporting metals to various mediums. For example, phytoplankton bloom can concentrate metal in sea water into biomass and increase bioaccumulation of metals in clams, eventually introducing significant amount of metals into food chain [75].

\section{Future Perspectives}

In summary, based on the analysis of the summarized information collected in this study, coastal sediment metal contamination should continue to raise our concern. It is not new that metal contaminations are still present in the world's estuaries and coastal areas. The current issues are how we can effectively exercise the contamination assessment, environmental protection, ecosystem restoration, and sustainable development of the coastal areas. In the future, more attention should be paid to develop more precise contamination evaluation and ecological risk assessment approaches as well as more sustainable remediation strategies for contaminated coastal sites.

Although the choice of geochemical normalization element is critical when evaluating the enrichment level of metals based on EF, a more accurate assessment should be achieved by choosing the local background values from adjacent sites with less anthropogenic disturbance [83]. It should also be noted that the HQ based on the total sediment concentration is only a conservative evaluation of the potential ecological risk of metal accumulated in the sediment because only the bioavailable fraction of metals can pose potential risk to the ecosystem [84]. Therefore, the actual ecological risk could be different from what is indicated by the HQ in this study as total metal concentration applied for the HQ calculation includes 
both bioavailable metal concentration and non-bioavailable metal concentration [84]. To properly estimate the actual ecological risk of metals accumulated in sediment, it is more important to determine the concentration of bioavailable metal [83].

Besides determining the fraction of bioavailable metals in total sediment metal concentration for the sediment risk assessment, metal speciation in sediment pore water is also highly concerned because not all the dissolved metals in the pore water are available for organisms to absorb. Dissolved metals in solution usually exist as free ions or associated with complexes (e.g., proton complexes, ligands, chelates) and organisms tend to uptake metals in free ion or small-molecular metal complex forms [85]. Furthermore, metal toxicity also varies with metal speciation. For example, As(III) is more toxic than $\mathrm{As}(\mathrm{V}), \mathrm{Cr}(\mathrm{VI})$ is more toxic than $\mathrm{Cr}(\mathrm{III})$, and methylated metals (e.g., methylated mercury) have higher toxicity $[84,86]$. Therefore, special attention should be given to the development of analytical approaches that can measure the concentration and speciation of dissolved metal in pore water effectively and accurately [87].

Finally, as sediment metal contamination is becoming a worldwide environmental issue, remediation strategies are needed to eliminate the potential environmental impacts on human health [88]. Conventional remediation techniques for contaminated sediment such as in situ capping, landfill disposal, and sea dumping were once very popular for coastal sediment remediation. However, these techniques are not long-term sustainable as contaminants are potentially mobile after the treatment. In the recent decades, new remediation techniques such as biological treatment, thermal treatment, and in situ chemical treatment are under development, which significantly increased the efficiency and reliability of sediment remediation [89]. The selection of an appropriate technique for a specific remediation project usually depends on human and ecological risk before and after the remediation. In recent years, it is proposed to apply life cycle assessment to assist the selection of ideal sediment remediation technique in order to take environmental footprint into consideration [90].

Acknowledgments This work was supported in part by the China Scholarship Council (YQ) and the State Key Laboratory of Estuarine and Coastal Research Open Research Fund (Ref no. SKLEC-KF201304).

\section{References}

1. Hill MK. Understanding environmental pollution. 3rd ed. New York: Cambridge University Press; 2010.

2. Martin J-M, Whitfield M. The significance of the river input of chemical elements to the ocean. In: Trace metals in sea water. Springer; 1983. p. 265-96.

3. Taylor SR, McLennan SM. The geochemical evolution of the continental crust. Rev Geophys. 1995;33:241-65.
4. Underwood E. Trace elements in human and animal nutrition 4e. Elsevier; 2012.

5. Feng H, Zhang W, Zhang L, Wang X-C, Yu L, Yu D. Heavy metal contamination in selected urban coastal regions in US and China. Hauppauge: Nova Science Publishers, Inc; 2008. p. 265-86.

6. Salomons W. Environmental impact of metals derived from mining activities: processes, predictions, prevention. J Geochem Explor. 1995;52:5-23.

7. Feng H, Cochran JK, Liwiz H, Brownawell BJ, Hirschberg DJ. Distribution of heavy metal and PCB contaminants in the sediments of an urban estuary: the Hudson River. Mar Environ Res. 1998;45: 69-88.

8. Onwueme V, Feng H. Risk characterization of contaminants in Passaic River sediments, New Jersey. Middle States Geogr. 2006;39:13-25.

9. Müller J, Ruppert H, Muramatsu Y, Schneider J. Reservoir sediments - a witness of mining and industrial development (Malter Reservoir, eastern Erzgebirge, Germany). Environ Geol. 2000;39: 1341-51.

10. Bothner M, Buchholtz ten Brink M, Manheim F. Metal concentrations in surface sediments of Boston Harbor - changes with time. Mar Environ Res. 1998;45:127-55.

11. Feng H, Han X, Zhang W, Yu L. A preliminary study of heavy metal contamination in Yangtze River intertidal zone due to urbanization. Mar Pollut Bull. 2004;49:910-5.

12. Feng H, Jiang H, Gao W, Weinstein MP, Zhang Q, Zhang W, et al. Metal contamination in sediments of the western Bohai Bay and adjacent estuaries, China. J Environ Manag. 2011;92:1185-97.

13. Forstner U, Wittman GTW. Metal pollution in the aquatic environment. New York: Verlag Publishers; 1983.

14. Santos IR, Silva-Filho EV, Schaefer CE, Albuquerque-Filho MR, Campos LS. Heavy metal contamination in coastal sediments and soils near the Brazilian Antarctic Station, King George Island. Mar Pollut Bull. 2005;50:185-94.

15. Bopp RF, Simpson HJ. Contamination of the Hudson River: the sediment record. In: Contaminated marine sediments assessment and remediation. 1989. p. 401-16.

16. Goldberg ED, Griffin JJ, Hodge V, Koide M, Windom H. Pollution history of the Savannah River estuary. Environ Sci Technol. 1979;13:588-94.

17. Qian Y, Feng H, Zhang W, Yu L, Zhu Q, Zhang L, Wang X. Environmental assessment of metal concentrations in selected riverine, estuarine and coastal sediments. In: Heavy metal sediments. Nova Science Publishers; 2011. p. 59-85.

18. Trefry JH, Shokes RF. History of heavy-metal inputs to Mississippi Delta sediments. Elsevier Oceanogr Ser. 1981;27:193-208.

19. Valette-Silver NJ. The use of sediment cores to reconstruct historical trends in contamination of estuarine and coastal sediments. Estuaries. 1993;16:577-88.

20. el-Nemr A, Khaled A, el-Sikaily A. Distribution and statistical analysis of leachable and total heavy metals in the sediments of the Suez Gulf. Environ Monit Assess. 2006;118:89-112.

21. Zourarah B, Maanan M, Carruesco C, Aajjane A, Mehdi K, Conceição Freitas M. Fifty-year sedimentary record of heavy metal pollution in the lagoon of Oualidia (Moroccan Atlantic coast). Estuar Coast Shelf Sci. 2007;72:359-69.

22. Cheggour M, Chafik A, Fisher NS, Benbrahim S. Metal concentrations in sediments and clams in four Moroccan estuaries. Mar Environ Res. 2005;59:119-37.

23. de Mora S, Sheikholeslami MR, Wyse E, Azemard S, Cassi R. An assessment of metal contamination in coastal sediments of the Caspian Sea. Mar Pollut Bull. 2004;48:61-77.

24. Topcuoğlu S, Kirbaşoğlu Ç, Yilmaz YZ. Heavy metal levels in biota and sediments in the northern coast of the Marmara Sea. Environ Monit Assess. 2004;96:183-9. 
25. Herut B, Hornung H, Krom MD, Kress N, Cohen Y. Trace metals in shallow sediments from the Mediterranean coastal region of Israel. Mar Pollut Bull. 1993;26:675-82.

26. Hong L-y, Hong H-s, Chen W-q, Wang X-h, Zhang L-p. Heavy metals in surface sediments from Minjiang Estuary-Mazu and Xiamen-Jinmen sea areas. J Environ Sci. 2003;15:116-22.

27. Li X, Wai OWH, Li YS, Coles BJ, Ramsey MH, Thornton I. Heavy metal distribution in sediment profiles of the Pearl River estuary, South China. Appl Geochem. 2000;15:567-81.

28. Zhang W, Feng H, Chang J, Qu J, Xie H, Yu L. Heavy metal contamination in surface sediments of Yangtze River intertidal zone: an assessment from different indexes. Environ Pollut. 2009; $157: 1533-43$.

29. Hyun S, Lee CH, Lee T, Choi JW. Anthropogenic contributions to heavy metal distributions in the surface sediments of Masan Bay, Korea. Mar Pollut Bull. 2007;54:1059-68.

30. Reddy MS, Basha S, Sravan Kumar VG, Joshi HV, Ramachandraiah G. Distribution, enrichment and accumulation of heavy metals in coastal sediments of Alang-Sosiya ship scrapping yard, India. Mar Pollut Bull. 2004;48:1055-9.

31. Jonathan MP, Mohan VR. Heavy metals in sediments of the inner shelf off the Gulf of Mannar, South East Coast of India. Mar Pollut Bull. 2003;46:263-8.

32. Loring DH, Nas K, Dahle S, Matishov GG, Illin G. Arsenic, trace metals, and organic micro contaminants in sediments from the Pechora Sea, Russia. Mar Geol. 1995;128:153-67.

33. Liaghati T, Preda M, Cox M. Heavy metal distribution and controlling factors within coastal plain sediments, Bells Creek catchment, southeast Queensland, Australia. Environ Int. 2004;29:935-48.

34. Maata M, Singh S. Heavy metal pollution in Suva harbor sediments, Fiji. Environ Chem Lett. 2008;6:113-8.

35. Celo V, Babi D, Baraj B, Çullaj A. An assessment of heavy metal pollution in the sediments along the Albanian Coast. Water Air Soil Pollut. 1999; 111:235-50.

36. Audry S, Sch fer J, Blanc G, Jouanneau JM. Fifty-year sedimentary record of heavy metal pollution $(\mathrm{Cd}, \mathrm{Zn}, \mathrm{Cu}, \mathrm{Pb})$ in the Lot River reservoirs (France). Environ Pollut. 2004;132:413-26.

37. Pazi I. Assessment of heavy metal contamination in Candarli Gulf sediment, Eastern Aegean Sea. Environ Monit Assess. 2011;174: 199-208.

38. Galanopoulou S, Vgenopoulos A, Conispoliatis N. Anthropogenic heavy metal pollution in the Surficial sediments of the Keratsini Harbor, Saronikos Gulf, Greece. Water Air Soil Pollut. 2009;202: 121-30.

39. Spagnoli F, Bartholini G, Dinelli E, Giordano P. Geochemistry and particle size of surface sediments of Gulf of Manfredonia (Southern Adriatic sea). Estuar Coast Shelf Sci. 2008;80:21-30.

40. Adamo P, Arienzo M, Imperato M, Naimo D, Nardi G, Stanzione D. Distribution and partition of heavy metals in surface and subsurface sediments of Naples city port. Chemosphere. 2005;61:8009.

41. Buccolieri A, Buccolieri G, Cardellicchio N, Dell'Atti A, Di Leo A, Maci A. Heavy metals in marine sediments of Taranto Gulf (Ionian Sea, Southern Italy). Mar Chem. 2006;99:227-35.

42. Fernandez Caliani JC, Ruiz Munoz F, Galan E. Clay mineral and heavy metal distributions in the lower estuary of Huelva and adjacent Atlantic shelf, SW Spain. Sci Total Environ. 1997;1997:181200.

43. Angel DelValls T, Forja JM, Gómez-Parra A. Seasonality of contamination, toxicity, and quality values in sediments from littoral ecosystems in the Gulf of Cadiz (SW Spain). Chemosphere. 2002;46:1033-43.

44. Santos Bermejo J, Beltrán R, Gómez Ariza J. Spatial variations of heavy metals contamination in sediments from Odiel river (Southwest Spain). Environ Int. 2003;29:69-77.
45. Jones B, Turki A. Distribution and speciation of heavy metals in surficial sediments from the Tees estuary, North-east England. Mar Pollut Bull. 1997;34:768-79.

46. Villaescusa-Celaya JA, Gutiérrez-Galindo EA, Flores-Muňoz G. Heavy metals in the fine fraction of coastal sediments from Baja California (Mexico) and California (USA). Environ Pollut. 2000;108:453-62.

47. Hwang HM, Green PG, Higashi RM, Young TM. Tidal salt marsh sediment in California, USA. Part 2: occurrence and anthropogenic input of trace metals. Chemosphere. 2006;64:1899-909.

48. Shumilin EN, Carriquiry JD, Camacho-Ibar VF, Sapozhnikov D, Kalmykov S, Sanchez A, et al. Spatial and vertical distributions of elements in sediments of the Colorado River delta and Upper Gulf of California. Mar Chem. 2002;79:113-31.

49. Kim G, Alleman LY, Church TM. Accumulation records of radionuclides and trace metals in two contrasting Delaware salt marshes. Mar Chem. 2004;87:87-96.

50. Bolton JL, Stehr CM, Boyd DT, Burrows DG, Tkalin AV, Lishavskaya TS. Organic and trace metal contaminants in sediments and English sole tissues from Vancouver Harbour, Canada. Mar Environ Res. 2004;57:19-36.

51. Fernandes HM. Heavy metal distribution in sediments and ecological risk assessment: the role of diagenetic processes in reducing metal toxicity in bottom sediments. Environ Pollut. 1997;97:31725.

52. Molisani MM, Salomao MSMB, Ovalle ARC, Rezende CE, Lacerda LD, Carvalho CEV. Heavy metals in sediments of the Lower Paraiba do Sul River and estuary, R.J., Brazil. Bull Environ Contam Toxicol. 1999;63:682-90.

53. Marchand C, Lallier-Vergès E, Baltzer F, Albéric P, Cossa D, Baillif $P$. Heavy metals distribution in mangrove sediments along the mobile coastline of French Guiana. Mar Chem. 2006;98:1-17.

54. Long ER, MacDonald DD, Smith SL, Calder FD. Incidence of adverse biological effects within ranges of chemical concentrations in marine and estuarine sediments. Environ Manag. 1995;19:8197.

55. GIPME. Guidance on assessment of sediment quality. In: Environment, global investigation of pollution in the marine environment. 1999.

56. Salomons W, Förstner U. Metals in the hydrocycle. SpringerVerlag; 1984.

57. Sinex SA, Wright DA. Distribution of trace metals in the sediments and biota of Chesapeake Bay. Mar Pollut Bull. 1988;19:425-31.

58. Windom HL, Schropp SJ, Calder FD, Ryan JD, Smith Jr RG, Burney LC, et al. Natural trace metal concentrations in estuarine and coastal marine sediments of the southeastern United States. Environ Sci Technol. 1989;23:314-20.

59. Windom H, Byrd J, Smith R, Hungspreugs M, Dharmvanij S, Thumtrakul W, et al. Trace metal-nutrient relationships in estuaries. Mar Chem. 1991;32:177-94.

60. Zhang J, Liu C. Riverine composition and estuarine geochemistry of particulate metals in China - weathering features, anthropogenic impact and chemical fluxes. Estuar Coast Shelf Sci. 2002;54:105170 .

61. Schropp SJ, Lewis FG, Windom HL, Ryan JD, Calder FD, Burney LC. Interpretation of metal concentrations in estuarine sediments of Florida using aluminum as a reference element. Estuaries. 1990;13: 227-35.

62. Sinex S, Helz G. Regional geochemistry of trace elements in Chesapeake Bay sediments. Environ Geol. 1981;3:315-23.

63. Covelli S, Fontolan G, Faganeli J, Ogrinc N. Anthropogenic markers in the Holocene stratigraphic sequence of the Gulf of Trieste (northern Adriatic Sea). Mar Geol. 2006;230:29-51.

64. Bergamaschi L, Rizzio E, Valcuvia M, Verza G, Profumo A, Gallorini M. Determination of trace elements and evaluation of 
their enrichment factors in Himalayan lichens. Environ Pollut. 2002;120:137-44.

65. Conrad CF, Chisholm-Brause CJ. Spatial survey of trace metal contaminants in the sediments of the Ellizabeth River, Virginia. Mar Pollut Bull. 2004;49:319-24.

66. Hernandez L, Probst A, Probst JL, Ulrich E. Heavy metal distribution in some French forest soils: evidence for atmospheric contamination. Sci Total Environ. 2003;312:195-219.

67. Isakson J, Oblad M, Selin Lindgren E, Djupstrom Fridell M, Pacyna J, Mäkinen M. Perturbation of background aerosol at rural sites in the Nordic countries. Atmos Environ. 1997;31:3077-86.

68. Lee C-L, Fang M-D, Hsieh M-T. Characterization and distribution of metals in surficial sediments in southwestern Taiwan. Mar Pollut Bull. 1998;36:464-71.

69. Mishra VK, Kim K-H, Kang C-H, Choi KC. Wintertime sources and distribution of airborne lead in Korea. Atmos Environ. 2004;38:2653-64.

70. Quevauviller P, Lavigne R, Cortez L. Impact of industrial and mine drainage wastes on the heavy metal distribution in the drainage basin and estuary of the Sado River (Portugal). Environ Pollut. 1989;59:267-86.

71. Reimann C, Caritat PD. Intrinsic flaws of element enrichment factors (EFs) in environmental geochemistry. Environ Sci Technol. 2000;34:5084-91.

72. Han Y, Du P, Cao J, Posmentier ES. Multivariate analysis of heavy metal contamination in urban dusts of Xi'an, Central China. Sci Total Environ. 2006;355:176-86.

73. Loska K, Wiechuła D. Application of principal component analysis for the estimation of source of heavy metal contamination in surface sediments from the Rybnik Reservoir. Chemosphere. 2003;51:72333.

74. Nolting R, Ramkema A, Everaarts J. The geochemistry of $\mathrm{Cu}, \mathrm{Cd}$, $\mathrm{Zn}, \mathrm{Ni}$ and $\mathrm{Pb}$ in sediment cores from the continental slope of the Banc d'Arguin (Mauritania). Cont Shelf Res. 1999;19:665-91.

75. Luoma SN. The developing framework of marine ecotoxicology: pollutants as a variable in marine ecosystems? J Exp Mar Biol Ecol. 1996;200:29-55.

76. Long ER, Field LJ, MacDonald DD. Predicting toxicity in marine sediments with numerical sediment quality guidelines. Environ Toxicol Chem. 1998;17:714-27.

77. Urban DL, Cook NJ. Hazard evaluation, standard evaluation procedure, ecological risk assessment. In: Agency EP, editor. Washington, D.C.; 1986.

78. Ingersoll CG, Haverland PS, Brunson EL, Canfield TJ, James Dwyer F, Henke CE, et al. Calculation and evaluation of sediment effect concentrations for the amphipod Hyalella azteca and the midge Chironomus riparius. J Great Lakes Res. 1996;22:602-23.

79. Long ER, Morgan LG. The potential for biological effects of sediments-sorbed contaminants tested in the National Status and Trends Program. Seattle: NOAA Tech Memo NOS OMA 52. U.S. National Oceanic and Atmospheric Administration; 1990. $175 \mathrm{pp}+$ appendices.

80. Sundaray SK, Nayak BB, Lin S, Bhatta D. Geochemical speciation and risk assessment of heavy metals in the river estuarine sediments - a case study: Mahanadi basin, India. J Hazard Mater. 2011;186:1837-46.

81. Wang X, Tao S, Dawson R, Xu F. Characterizing and comparing risks of polycyclic aromatic hydrocarbons in a Tianjin wastewaterirrigated area. Environ Res. 2002;90:201-6.

82. Filgueiras A, Lavilla I, Bendicho C. Evaluation of distribution, mobility and binding behavior of heavy metals in surficial sediments of Louro River (Galicia, Spain) using chemometric analysis: a case study. Sci Total Environ. 2004;330:115-29.

83. Sakan S, Devic G, Relic D, Andelkovic I, Sakan N, Dordevic D. Evaluation of sediment contamination with heavy metals: the importance of determining appropriate background content and suitable element for normalization. Environ Geochem Health. 2015;37: 97-113.

84. Alloway BJ. Heavy metals in soils, trace metals and metalloids in soils and their bioavailability. 3rd ed. Springer; 2010.

85. Sposito G. The chemistry of soils. 2nd ed. New York: Oxford University Press; 2008.

86. Mason PR. The methylation of metals and metalloids in aquatic systems. Chap 11. In: Dricu A, editor. Methylation - From DNA, RNA and Histones to Diseases and Treatment. 2012. p. 271-301.

87. Pan K, Wang WX. Trace metal contamination in estuarine and coastal environments in China. Sci Total Environ. 2012;421-422: 3-16.

88. Akcil A, Erust C, Ozdemiroglu S, Fonti V, Beolchini F. A review of approaches and techniques used in aquatic contaminated sediments: metal removal and stabilization by chemical and biotechnological processes. J Clean Prod. 2015;86:24-36.

89. Reis E, Lodolo A, Miertus S. Survey of sediment remediation technologies, 2007. 2011. Available on line at www.ics.trieste.it/media/ 117892/df5310.pdf.

90. Sparrevik M, Saloranta T, Cornelissen G, Eek E, Fet AM, Breedveld GD, et al. Use of life cycle assessments to evaluate the environmental footprint of contaminated sediment remediation. Environ Sci Technol. 2011;45:4235-41. 